\title{
A Sociocognitive Perspective of \\ INDUSTRY-LEVEL COLLECTIVE STAKEHOLDER ACTION: THE CASE OF THE SCOTCH WHISKY INDUSTRY
}

\author{
Natasha Vijay Munshi \\ City University London \\ London, UK
}

\begin{abstract}
This paper explores industry-level, collective stakeholder action. It argues that industry stakeholders will act collectively at the industry level when they perceive change to be radically in conflict with their shared beliefs. Although collective action may not be in their immediate economic self-interests, this type of industry level collaboration is undertaken with the long-term interest of the collective industry in mind. The example of the Scotch whisky industry is used here to illustrate such collaborative industry-level collective stakeholder action.
\end{abstract}

\section{Introduction}

Mancur Olson's (1965) treatise 'The Logic of Collective Action,' has long influenced the way economists have treated the subject of collective action. Theorists such as Olson have reasoned that the basis for collective action is a pure rational one of looking out for one's own immediate self interest rather than the collective benefits that could result out of collaboration. If one was to use this rationalist perspective to study collective stakeholder action at the industry level, then one should observe collaborative action only when each 'rational' actor perceives his/her individual economic interest or stake to be in danger rather than that of the collective group. The self interest motive is the case in many instances of observed collective action. However, this perspective does not explain the collective action of actors who appear to be acting against their own immediate economic interests. By subsuming their own interests to those of the collective, these actors appear to be giving up their own economic gain in the short run. This paper's main purpose is to examine what drives collective stakeholder action at the industry level. It uses the sociocognitive perspective (Fiske and Taylor, 1991) as its theoretical lens to study this question in order to provide an alternative viewpoint to the rationalist economics based perspective of collective action.

The paper next briefly reviews the relevant literature on how social cognition is involved in the evolution of industry structure. It also provides a short overview of the extant research on the stakeholder's perspective. This paper uses the extant stakeholder literature (Freeman, 1984; Frooman, 1999; Mitchell, Agle, and Wood, 1997; Rowley and Moldoveanu, 2003) and the literature on the social and cognitive 
aspects of industries (Abrahamson and Fombrun, 1994; Christensen and Gordon, 1999; Daniels, Johnson, and Chernatony, 2002; Porac and Thomas, 1995; Porac, Thomas, and Baden-Fuller, 1989; Spender, 1989) as its theoretical underpinning in order to further investigate this research phenomenon. It then follows with a brief description of the events associated with the introduction of the Cardhu Pure Malt whisky in the Scotch whisky industry. The paper then discusses the factors contributing to industry-level stakeholder group action in traditional industries and concludes with implications of this study for scholars and for practitioners who are interested in learning more about the stakeholder concept.

\section{Literature Review}

Prior research on firm-stakeholder relationships has focused mainly on managerial cognition, i.e., how managers perceive and manage their stakeholders (Freeman, 1984; Mitchell, Agle, and Wood, 1997; Agle, Mitchell, and Sonnenfeld, 2000). However, relationships are embedded within their social context (Rowley, 2000). Studying a single firm's relationship with a single stakeholder doesn't capture the full complexity of the effects of the social context on such relationships. A better understanding can only be gained when these interactions can be studied within the broaden context in which they are embedded. This paper addresses the issue of collective stakeholder action in one such context, namely the industry context, as not much is known about collective stakeholder action at this level of analysis within the extant stakeholder research.

Furthermore, there is a dearth of knowledge on the stakeholder's perspective of the relationship that has only recently been addressed by new research on stakeholder action (Frooman, 1999; Rowley, 1997, 2000; Rowley and Moldoveanu, 2003). Frooman's (1999) study applied concepts from resource dependence theory to argue that stakeholders can act together - by using either direct or indirect access to resources - to influence the focal firm's behaviour. In another study that takes a stakeholder's perspective, Rowley and Moldoveanu (2003) examined stakeholder groups' propensity for action. They proposed that an interest based rationale is a necessary but insufficient condition for when stakeholder groups will mobilize to act. They concluded that when group identity is highly valued by the members of the group, this is likely to rally stakeholder groups to act even when there are no economic benefits to be obtained through such action. This line of research is built on to address collective stakeholder action at the industry level.

\section{The Industry Context}

To determine what are the boundaries of an industry, Porter defined an industry as 'the group of firms producing products that are close substitutes for each other' (1980, p. 5). Based on industrial organization (IO) economics, Porter's framework for industry analysis has pervaded academic and practitioner literature as a means by which to analyze industry competitive behaviour and profitability. Porter in- 
cludes buyers, suppliers, potential and existing rivals within this framework as those actors that constitute part of an industry's immediate task environment.

However, this conventional view of an industry's structure is limiting and does not provide an accurate picture of who constitutes a stakeholder of an industry. There is research to suggest that industries are not merely clusters of competing firms, but social and cognitive systems in their own right (Porac and Thomas, 1995; Porac, Thomas and Baden-Fuller, 1989; Reger and Huff, 1993). Grinyer and Spender's (1979) research, and later on, Spender's dissertation work (1989) would suggest that industries generate 'recipes' or patterns of belief that rely on common knowledge and shared experiences. Other research, by Porac and colleagues (Porac and Thomas, 1995; Porac, Thomas and Baden-Fuller, 1989) on the Scottish knitwear industry, provided empirical evidence that industries are socially constructed based on patterns of beliefs of those who perceive themselves as members. Social cognition theories (Fiske and Taylor, 1991) inform us that social realities are constructed based on mutually shared perceptions between individuals. This paper hopes that the social constructionist perspective can help shed light on stakeholder group action in an industry context.

More recent work on industry level social cognition tries to reconcile the economist's view with that of the cognitive view. This research suggests that the 'stickiness' of these underlying belief patterns of industry members may be at risk when economic opportunities arise (Johnson and Hoopes, 2003). It is possible then that the socially constructed beliefs of members will be challenged by any perceived innovative change that is radically different from the prevailing values and beliefs of intra-industry stakeholders, which could lead to potential for stakeholder action. In the next section, the existing literature on the stakeholder's perspective is reviewed in brief to identify who might be considered industry stakeholders and why these actors act collectively at the industry level.

\section{The Stakeholder's Perspective}

Stakeholder researchers (e.g., Mitchell, Agle, and Wood, 1997; Agle, Mitchell and Sonnenfeld, 2000) have been preoccupied with managers' perception of stakeholders and how to manage these stakeholders. However, Freeman (1984) defines a stakeholder as "any group or individual who can affect or is affected by the achievement of the organization's objective" (p. 46). Thus, it is important to clarify that stakeholders can act to influence a firm just as well. Until recently, not much was known about this stakeholder's perspective, especially in terms of how stakeholder groups can collectively act to influence a focal organization's behaviour. Frooman (1999) notably used resource dependence theory to suggest that stakeholder influence strategies were based on gaining resource access. This original study concluded that stakeholders act either directly or indirectly to gain access to resources in order to influence the focal organization.

Rowley and his co-authors have also suggested there is a need to take into account the social context to study stakeholder-firm interactions within a network of relationships. For example, Rowley (1997) took a social network approach 
to study this research problem and found empirical support for the importance of the relational context (Rowley, 2000). Furthermore, Rowley, Behrens, and Krackhardt (2000) noted the importance of industry context on such types of relationships. More recently, Rowley and Moldoveanu (2003) provide additional insight on when multiple stakeholders will mobilize for action, i.e., intention rather than actual action. They argued that stakeholders are most likely to take collective action when they are both protecting their interest and are bounded by their shared identity based on group membership. These works represent a significant advance in stakeholder literature as they attribute motives to observed behavior.

This paper attempts to extend this line of research on when multiple stakeholders will act collectively by addressing the phenomenon at the industry level of analysis. Rowley and Moldoveanu (2003) use group membership as the basis for identifying what constitutes a stakeholder group. For the purposes of this paper, industry stakeholders are identified as those individuals and groups who perceive themselves and are perceived by other members as having a membership stake in the industry. It can be said then that industry stakeholders have a shared mental model of the industry that is based on mutually shared beliefs. Below, the events that unfolded following the introduction of the Cardhu pure malt whisky by Diageo into the Scotch whisky industry are used as an illustration of stakeholder action at the industry level.

\section{Research Setting}

In this study, collective stakeholder action is examined within the context of the Scotch whisky industry. The specific example of multiple stakeholder action against the introduction of a new product by Diageo, namely the Cardhu 'pure' malt whisky is used as an illustrative example of stakeholder action at the industry level. There are several reasons why the Scotch whisky industry is useful in this paper in order to explain this phenomenon. For one, it is a traditional industry. Industry stakeholders used to be bounded by traditions and norms that comprise commonly held beliefs. This has recently changed with the takeover of many smaller distilleries by large multinational corporations that are more concerned with global scale economies as they operate at the global level. This is an industry going through rapid changes, especially at the corporate level. But it is still bounded by traditions and commonly held beliefs at the production level, which makes this a fertile ground to observe industry level collective stakeholder action. This section is followed by a brief discussion of how social cognitive processes rather than purely rational motivations might have contributed to why stakeholders collectively acted at the industry level in this example. Further illustrations are provided in the form of excerpts taken from first-person interviews with key industry actors such as distillery managers and distillery owners on the production end, expert sources such as Whisky magazine, the Scotch Whisky Association, and specialist retailers and whisky connoisseurs on the consumer 
marketing end. These interviews were compiled as part of an ongoing research study on the Scotch whisky industry.

\section{The Scotch Whisky Industry and the Cardhu Pure Malt Whisky Incident}

This main purpose of this paper is to examine collaborative stakeholder action at the industry level from a sociocognitive perspective. The Scotch whisky industry is used as a case in point. According to the Scotch Whisky Industry's trade association (SWA), Scotch whisky is one the top five exports from the UK as it makes up over $20 \%$ of UK food and drink exports with income exceeding $£ 2$ Billion per year in the last decade (Scotch Whisky Association, 2005). It is also noted by the SWA that with over 10,000 employees drawn from local regions, the Scotch whisky industry is a major manufacturing industry in Scotland and furthermore, Scotch whisky outsells its closest rivals by four times in terms of sales.

In the production of Scotch whisky, there are many actors involved in the process of delivering the final product to the consumer. These individuals can be found in various parts of the production process such as the malting, mashing, fermentation, distillation, maturation, and beyond that to the warehousing, blending, bottling and packaging processes, as well as in distribution, advertising and marketing. Other industry members include the cereal producers and suppliers, energy producers, distributors, and retailers. In addition, there are other key stakeholders such as the experts and connoisseurs, the whisky clubs and other associations on the internet who also contribute in developing narratives and myths behind the Scotch whiskies and are, therefore, also stakeholders in the social construction process.

Scotch whisky traditionally comprises the spectrum of product categories from blended to single malt whiskies. Prior to the Cardhu incident, it was commonly understood that a blended whisky was made up of single malts and/or grain whiskies from several distilleries while a 'single' malt whisky was from just one distillery. A 'single' malt Scotch whisky is the product of one Scottish distillery, and by law, is required to be matured for a minimum of 3 years in Scotland prior to sale. In reality, most single malts are matured for a minimum of 10 years prior to being sold as single malts, which has raised serious concerns as demand has begun to outstrip supply due to the increasing global popularity of this product category (Coyle, 2003). Simply put, although the actual single malt product in the bottle maybe a 'vatting' or marriage of several different years, the whisky should have come from one distillery only to be called a 'single' malt - the implicit and generally understood but unwritten rule was that, if the product was a mixture of single malts from different distilleries, then it was to be referred to as a vatted malt whisky or even a blend.

For Diageo - Cardhu distillery's parent company and the largest firm in the industry - the introduction in April 2003 of the Cardhu 'pure malt' whisky was seen as an innovative solution to the production shortage faced by the whisky industry in their fast growing single malt sector (Diageo News Release, 2003). 
The pure malt had been packaged and sold in Cardhu's overseas markets in exactly the same way as its single malt whisky, although technically the 'pure' malt product had single malts from Diageo's other distilleries in it as well and in the opinion of Diageo's competitors, should have been referred to as vatted malt. For Diageo's brand director, Jonathan Driver, Cardhu pure malt presented an opportunity in a fast growing market to increase product categories and generate greater revenues (Diageo News Release, 2003). It appeared that Diageo's managers also thought that this pure malt category would be a revenue generator for other distillery owners facing similar shortage problems.

Discord on this issue, however, was based on what industry stakeholders perceived as a clash between Diageo's representation of the pure malt and what the single malt whisky category stood for. One distillery manager commented on the dilemma faced by Diageo:

"that was a marketing whoopsie... Cardhu was so successful from a marketing perspective that it outsold its production. Now given that there's a twelve year wait on production, you can't simply produce overnight for tomorrow, so had they (Diageo) known twelve years ago that they were going to be as successful in Spain, then they would have increased the size and capacity of Cardhu distillery. What they had originally was access to a market that wanted more Cardhu and they looked at producing more Cardhu simply by changing the goal posts and fundamentally changing the labelling on the whisky ... and that would have brought the whole malt whisky category into some disrepute around the world if it had been allowed to go ahead"

The problem was made worse by the fact that until this time, what constituted a 'single' malt and what constituted a 'blend' was based on common understanding rather than codified definitions (this definition has since been somewhat but not entirely resolved by the Scotch Whisky Association, the trade organization for the Scotch whisky industry). Despite the fact that there was some short-term economic gain from the introduction of the pure malt concept for many of the individual distilleries facing production shortages, the general feeling was that this was a bad move for the industry. Some stakeholders were reported to claim that the pure malt was bound to result in consumer confusion, which could lead to a dilution of the Scotch single malt whisky's reputation (Scotman.com, 2003). These stakeholders included not just Diageo's main competitors, but also connoisseurs, consumers, retailers, media, the UK and European governments. As one distillery manager succinctly put it:

".. (Single malt Scotch) is the only one today people are going to because they have a bit of trust in the product"

(July 2, 2004)

The outcome of a much publicized intra-industry battle was that Diageo finally pulled Cardhu 'pure' malt off the markets in 2004. The final resolution of the issue was brought about through an SWA initiated discussion and was generally 
perceived as being an amicable one. Ian Meakins, the head of Diageo's European marketing operation, issued a public statement stating among other reasons for this withdrawal: "We believe that we have acted consistently in the best interests of consumers, but acknowledge that we under-estimated the strength of feeling on this issue" (BBC News Online, 2004). Interestingly enough, many of the distillery managers interviewed perceived the entire problem as having originated on the marketing rather than the production side. One distillery manager who has been part of the industry for over 35 years stated:

"From a production standpoint, we have our brotherhood where everybody helps one another. I think where marketing and sales is concerned is probably where it gets slightly more vicious. That's where the competition comes in! But I can go and speak to other distillers about what's going on at their distilleries, ask them questions about their production and so on, walk around the plant with them."

(July 2, 2004)

Furthermore, the manager said:

"I think initially we were embarrassed and after it was all tidied up, I think there were little upsets... but we're all part of the Scottish whisky association of Scotland and we all sit around the table together...we've still got work to do and we've still got things that we need to fight as a body beyond the Cardhu incident..."

(July 2, 2004)

\section{Discussion}

The sociocognitive approach was used in this paper to demonstrate when stakeholders will act collectively at the industry level for the collective's interests at the expense of their own immediate short-term economic interests. There are several reasons for why this incident in the Scotch whisky industry illustrates industry-level collective stakeholder action that evolves from social construction. First of all, it is an industry whose reputation is built on traditions held together by collective beliefs of the industry members. It is said that commonly held beliefs shape social construction of the industry (Porac and Thomas, 1995). One reason for why the intra-industry stakeholders acted in unison to oppose the 'pure' malt category was to prevent change in their commonly held beliefs in regards to what they perceived the product categories represented. It is plausible that the intra-industry stakeholders' expectations regarding what was best for the industry was based on their collective perception of what would be in the interest of the industry's long term viability. It can be argued that as the intra-industry stakeholders collectively tried to make sense of the pure malt product, the stakeholders perceived it to be inconsistent with their shared beliefs regarding what single malt category represented.

Furthermore, the Scotch whisky industry's stakeholder actions were primarily driven by their collective identity (Rowley and Moldoveanu, 2003), which led to 
their action on the Cardhu pure malt whisky issue. It is argued here that in unique, traditional industries, the one reason why stakeholders are more likely to rally to action as compared to stakeholders in other industries, is because their individual identities are tied to those of the industry collective and this could take precedence over their economic interests. It is possible that one reason why intra-industry stakeholders were mobilized to act in this case is because their collective identity could be the coordinating mechanism enabling collective gains, as opposed to taking the short-term self interested option for individual gain.

This paper puts forth one explanation for why traditional industries in particular are so idiosyncratic in their stakeholder actions. It suggests that industries' stakeholder action can be unique in themselves because of the interactions between socially constructed representations of actors and institutions, both internally and externally. These socially constructed representations in industries take the form of narratives and beliefs that stakeholders of the industry can collectively and individually identify with. As seen in the case of the Scotch whisky industry, the production side of the whisky industry perceived as a 'brotherhood' among all the distillery producers with a shared tacit understanding of what the industry's products represent. These render a far more complex picture for why stakeholders mobilize than Porter's industry analysis would allow for. To the extent then that industry stakeholders perceive change as being at odds with mutually shared beliefs, there is a greater likelihood of collective stakeholder action at the industry level.

Proposition: When industry stakeholders perceive change to be in discord with mutually shared beliefs, there is greater chance of collective stakeholder action at the industry level

Industries differ in the variety of stakeholders associated with them, in what these stakeholders value and how these stakeholders cognitively make sense of what constitutes the 'industry.' Just as stakeholder maps exist for an individual firm that constitute a group of idiosyncratic stakeholders within a network of relationships, so too within a particular industry, there can exist industry stakeholders that have a shared mental schema or model of what the industry constitutes. It is possible that these stakeholders generate a socio-cognitive map that is closely tied to a collective identity, which when disturbed through the introduction of radically perceived change, could result in industry-level stakeholder action.

It is said that commonly held patterns of beliefs make up the social construction of an industry (Porac and Thomas, 1995). It is plausible that these belief patterns would be strongly reinforced by stakeholders of traditional industries especially, where they perceive their values and beliefs as being closely identified with that of the industry. In the example of the Scotch whisky industry, the industry stakeholders have similar beliefs and values that overlap to such an extent that as a result, any change that is perceived as being radically different and not in accordance with the existing cognitive schema will result in a higher likelihood 
of stakeholder group action at a collective level. In contrast, it is plausible that in industries characterized by rapid changes such as nanotechnology or biotechnology, the industry schema is based on the introduction of radical innovations. One could say that there is a taken-for-grantedness about change that is incorporated into the cognitive schema of the stakeholder groups of these industries. Thus, these stakeholders are less likely to act when they perceive radical change. Interest based action (Rowley and Moldoveanu, 2003) is more likely to be the motive for stakeholder group action in such competitive industries.

\section{Conclusion and Implications}

This paper addresses collective stakeholder action at the industry level to better understand when stakeholders are motivated to act in a way that does not reflect a purely short-term economic reasoning for their actions. This paper illustrates this type of industry-level stakeholder action by using the example of the introduction of the Cardhu pure malt whisky in the Scotch whisky industry. It integrates stakeholder and sociocognitive perspectives on collective group action to explore when intra-industry stakeholders will act collectively at the industry level.

It puts forth one explanation for why industry level stakeholder action can occur. It suggests that industries constitute socially constructed representations of individuals and groups that perceive themselves as having a membership stake in the industry. These socially constructed representations in industries take the form of shared narratives and beliefs with which stakeholders of the industry can collectively and individually identify. Thus, changes that are perceived as being radically different from these shared mental models will increase the chances of industry level collective stakeholder action.

The collective stakeholder action at the industry level demonstrates that the 'The Tragedy of the Commons' (Hardin, 1968) is not always the case. The Tragedy of the Commons perspective argues that stakeholders will forsake their long-term collective benefits for their immediate short-term economic self- interests. This perspective has also been the foundation for various game theoretical models of industry level competitive action. The sociocognitive approach developed in this paper showed that the Tragedy of the Commons framework does not help to explain stakeholder action in the Scotch Whisky industry. Here we see that the stakeholders collaborated at the industry level in order to protect the reputation of the collective industry, subsuming any short-term economic gains they might have received from also going down the same road. The collective action of the Scotch whisky industry's stakeholders at the industry level provides an intriguing example of what can be referred to as 'The Joy of the Commons.'

Although this paper is limited by its focus on a single industry, its contribution is that it provides a more fine-grained explanation for why stakeholders act collectively at the industry level than a simple industry analysis based on Porter's five forces framework. The paper also provides further support for Rowley and Moldoveanu's (2003) theoretical framework for collective stakeholder group action 
that is identity based. One important implication of this study is that as firm level stakeholder action may be contingent upon industry effects, studying industry attributes might provide further clues for how firm-stakeholder relationships evolve.

For managers, this study also provides one explanation for why stakeholders will collaborate to act collectively against the focal firm. It also provides an insight into competitive strategies that are not purely driven by economic self interest as supported by rationalist economics driven theories. From the practitioners' point of view, using the social constructionist perspective developed here in addition to the rationalist economics based approaches achieves a more balanced approach to industry analysis and collective stakeholder action at the industry level.

\section{References}

Agle, B. R., Mitchell, R. K., \& Sonnenfeld, J. A. (2000). A report on stakeholder attributes and salience, corporate performance, and CEO values. In J. M. Logsdon, D. J. Wood, \& L. E. Preston (Eds.), Research in Stakeholder Theory. 1997-1998: The Sloan Foundation Minigrant Project, 39-54. Toronto, ON: Clarkson Centre for Business Ethics.

Abrahamson, E. \& Fombrun, C. J. (1994). Macrocultures: Determinants and consequences. Academy of Management Review, 19, 728-756.

Coyle, M. (2003). Icy stand-off in whisky row. BBC News Online. Retrieved November 7,2003 , from news.bbc.co.uk/1/hi/scotland/3249865.stm

Christensen, E. W. \& Gordon, G. G. (1999). An exploration of industry, culture and revenue growth. Organization Studies, 20, 397-423.

Daniels, K., Johnson, G., \& DeChernatony, L. (2002). Task and institutional influences on managers' mental models of competition. Organization Studies, 23, 31-62.

Diageo admits Cardhu malt defeat. BBC News Online. (2004). Retrieved March 9, 2004, from news.bbc.co.uk $/ 1 / \mathrm{hi} /$ scotland $/ 3546321 . \mathrm{stm}$

Diageo News Release.(2003). So is Cardhu pure malt a threat to Scotch Whisky? Retrieved November 17, 2003, from www.diageo.com/pageengine.asp?menu id $=0 \&$ site id $=1$ \&section_id $=2$ \&page_id $=1050$

Fiske, S. T. \& Taylor, S. E. (1991). Social Cognition. 2nd Edition. New York: McGrawHill, Inc.

Freeman, R. E. (1984). Strategic Management: A Stakeholder Approach. Boston: Pitman.

Frooman, J. (1999). Stakeholders influence strategies. Academy of Management Review, 24: 191-205. 
Grinyer, P. H. \& Spender, J-C. (1979). Recipes, crises and adaptation in mature industries. International Studies of Management and Organization, Vol. IX (3), 113-133.

Hardin, G. (1968). The tragedy of the commons. Science, 162, 1243-1248.

Johnson, D. R. \& Hoopes, D. G. (2003). Managerial cognition, sunk costs, and the evolution of industry structure. Strategic Management Journal, 24, 1057-1069.

Mitchell, R. K., Agle, B. R., \& Wood, D. J. (1997). Toward a theory of stakeholder identification and salience: Defining the principle of who and what really counts. Academy of Management Review, 22, 853-886.

Olson, M. (1965). The Logic of Collective Action: Public Goods and the Theory of Groups, Cambridge, MA: Harvard University Press.

Porac, J. F. \& Thomas, H. (1995). Rivalry and the industry model of Scottish knitwear producers. Administrative Science Quarterly, 40, 203-228.

Porac, J. F., Thomas, H., \& Baden-Fuller, C. (1989). Competitive groups as social communities: The case of the Scottish knitwear manufacturers. Journal of Management Studies, 26, 397-416.

Porter, M. E. (1980). Competitive Strategy: Techniques for analyzing industries and competitors. New York: The Free Press.

Post, J. E., Preston, L. E., \& Sachs, S. (2002). Managing the extended enterprise: the new stakeholder view. California Management Review, 45 (1), 6-28.

Reger, R. K., \& Huff, A. S. (1993). Strategic groups: A cognitive perspective. Strategic Management Journal, 14 (2), 103-123.

Rowley, T. J. (1997). Moving beyond dyadic ties: A network theory of stakeholder influences. Academy of Management Review, 22, 887-910.

Rowley, T. J. (2000). Does relational context matter? An empirical test of a network theory of stakeholder salience. In J. M. Logsdon, D. J. Wood, \& L. E. Preston (Eds.), Research in stakeholder theory, 1997-1998: The Sloan Foundation Minigrant Project: 2I-38. Toronto, ON: Clarkson Centre for Business Ethics.

Rowley, T. J., Behrens, D., \& Krackhardt, D. (2000). Redundant governance structures: An analysis of structural and relational embeddedness in the steel and semiconductor industries. Strategic Management Journal, 21, 369-386.

Rowley, T. J., \& Moldoveanu, M. (2003). When will stakeholder groups act? An interestand identity- based model of stakeholder group mobilization. Academy of Management Review, 28, 204-219. 
Scotch Whisky Association. (2005). Retrieved January 6, 2005, from www.scotch-whisky. org.uk

Spender, J-C. (1989). Industry recipes, the nature and sources of managerial judgment. Oxford: Basil Blackwell.

Whisky sour as deal leaves a nippy taste. 2003. Scotman.com. Retrieved December 5, 2003, from www.scotchwhisky.net/news/sour.php

Natasha Vijay Munshi, BSc, MCS, MBA, PhD, is an Assistant Professor in Strategy at Cass Business School, City University London, and an Advanced Institute of Management (AIM) Research Scholar. She teaches, publishes and advises in the areas of technology strategy, leadership and innovation, corporate social responsibility and stakeholder relationship management. 